\title{
Survey of Employability Skills Possessed by Undergraduates in Kwara State, Nigeria
}

\author{
Abdulrasaq Olatunji Balogun
}

\begin{abstract}
Graduate unemployment has been a continual challenge in Nigerian society due to graduates' inability to meet up with the current expectations of the labour market. These worries have been given serious attention in the present labour market. The employers, school authorities and policymakers continue to emphasize the importance of 'employability skills' in order for graduates to be fully equipped in meeting the challenges of an increasingly flexible labour market as these skills are rarely taught in the school. This study surveyed the employability skills possessed by undergraduates in Kwara state, Nigeria while the target population was undergraduates at the University of Ilorin, Kwara State, Nigeria. Specifically, the study investigated the level of employability skills, the perceived factors influencing the employability of undergraduates, the extent of self-development skills and job searching techniques as well as the interview skills possessed by undergraduates. Descriptive research based on survey design was employed. A sample of 353 students were drawn from a population of 4,362 students who participated as respondents. The Survey of Employability Skills of Undergraduates Questionnaire (SESUQ) was used as an instrument for data collection and the instrument's reliability coefficient of $0.82,0.84,0.86$ and 0.76 were obtained via Cronbach Alpha. Frequency, percentage, mean and standard deviation were employed for analysis. The results obtained signify that the employability level of undergraduates at the University of Ilorin was at an average level. Among others, a recommendation was made that the University management should, as a matter of urgency, create a graduate employability programme that includes such employability techniques as interview skills, job searching skills, entrepreneurial skills and self-development skills.
\end{abstract}

Keywords: Employability, determinants, employability skills, self-development skill, interview skills, job searching techniques 
Balogun, Abdulrasaq Olatunji is a lecturer in the Department of Social Sciences Education, Faculty of Education, University of Ilorin, Ilorin, Nigeria. His research interests include social problems, internally displaced persons and family and school crime. Recently published papers include: Balogun, A.O. Obimuyiwa, G. A, Abdulaziz, I. \& Oniye, R.K. (2019) Prevalence and determinants of sexting behaviour among undergraduates in Kawara State. Journal of Education and Learning, 13 (4), 567-574; Balogun, A.O., Jimoh, M.I., Okafor, I.P., Iyekolo, A.O. \& Abdulaziz, I. (2016). Assessment of educational and skill acquisition needs of internally displaced persons in Kaduna, Nigeria. Journal of Education in Developing Areas, University of Porthacourt, 24 (1), 42-49; and Balogun, A.O., Jimoh, M.I., Okafor, I.P., Oniye, R.K., Iyekolo, O.A., Igudia, H.I. \& Muhammad, G.M.F. (2017). Lecturers' perception of causes of unemployment among educated youths in Nigeria: The social implications. Journal of Research and Development in Education, 7 (1), 48-55. 


\section{Introduction}

Education has been the priority of the majority of African countries including Nigeria as a nation. This is because through education, a nation can invest in the people and it is the people that will converge in nation-building thereafter. In light of this, education is essential for economic and social development and for meeting the needs of the knowledge economy. The Federal Government of Nigeria (FGN, 2009) states that the sole aim of education is to make citizens of the country more resourceful, patriotic, free from mental colonization, and independent. That is, the education of a country must serve the purpose of increasing citizen's quality of life and provide them with requisite skills needed to be gainfully employed. Higher education plays a significant role in students' all-round development, most especially in the area of cognitive, psychomotor and affective domains of learning. These domains of learning are prospective traits to be advanced in learners as it ensures overall advancement of the physical, psychological, emotional and intellectual capabilities of the learner as they are important in employability skills development (Akhuemonkhan, Raimi \& Sofoluwe, 2013).

Nigeria education, according to FGN (2009), is subdivided into three areas which includes primary, secondary and tertiary education. The essence of primary education is to build a foundation or preparatory ground for the learner with manipulative capabilities in order to be morally sound and contribute meaningfully to the betterment of the country. Also, secondary education prepares learners with certain job-specific skills (e.g., entrepreneurial, vocational and technical education skills for their independence). Tertiary education, is capitalized and builds on the initial skills learners have gained in order to prepare them for labour market. Higher education, in discharging it duties, offers various opportunities for the less privileged to compete favourably in the labour market (Harry, Chinyamurindi \& Mjoli, 2018). Sodipo (2014) was of the opinion that the activities learners were exposed to in the schoolroom were solely based on concepts and not (at all times) on marketable skills. Marketable skills suggest that potential graduates are presupposed not to be adequately equipped with necessary life skills such as critical thinking, problem-solving, emotional intelligence, self-development skill, good character, organization skills, and leadership skills in addition to professional competence in their various field of specialization. There is thus the need for employability skills which will be valuable assets to enhance employability amongst graduates (Jackson, 2014).

Today's literature have demonstrated that the employability concept has gained wider recognition among scholars as a subject of study (Artess, Mellors-Bourne \& Hooley, 2017). Regardless of variances in the description of 'employability', mutual ground can be established (Harry, Chinyamurindi \& Mjoli, 2018). Jeswani (2016) describes employability as an ability required by graduates in gaining and sustaining employment opportunities. Chavan \& Carter (2018) note that employability, though, not an assurance to obtaining automatic employment, nonetheless, it improves employment probabilities. Lourens (2016) averse that institutions of learning provides noble opportunities for students' personal development, their satisfaction and monetary benefits. Based on this, students see employment opportunities as the cardinal thrust for seeking higher education. Nevertheless, an insufficient education system has hindered the employment prospects of students in present day Nigerian society. There has been 
regular bottlenecks in the system, particularly regarding a return on investment based on education inputs (Tholen, 2015). On this note, it is of immense importance for the stakeholders in education in conjunction with appropriate authorities to plan a school programme in a manner that will equip undergraduates with knowledge and understanding on how they could become self-employed and an employer of labour as well. Most important, is the enhancement of their employability skills.

If students have been grounded and acquire an in-depth knowledge of employability skills, it will give the individual student the opportunity to be conscious of their would-be skills, attitudes, and ability to turn into active citizens in the workforce (Artess , Mellors-Bourne \& Hooley, 2017). However, student mindfulness in relation to employability is sometimes ignored (Tymon, 2013). This remains unmapped in Nigeria. Furthermore, these skills are significant to employers and employees when considering the novel changes of an organization. In contemporary society, logical expansions demand that producers catch up with consumers' needs for low-priced and high-value goods. So, to be relevant in the realm of work, graduates must be aware and put into use the technological skills acquired to provide immediate solutions to the problems. They must also ensure the spirit of efficient communication, teamwork, and they must shoulder accountability, for valuable output. Hereafter, tertiary institutions put into operation the curriculum that places more emphasis on the improvement of soft skills. However, this does not help graduates enough to help them secure and maintain available job opportunities. Eventually, if maximum output is to be achieved, it must be combined with physical skills (Dania, Bakar \& Mohamed, 2014; Kraimer, Greco, Seibert \& Sargent, 2019). Similarly, Chillas, Marks \& Galloway (2015) hold the view that it is imperative for tertiary institutions to recognize student standpoints on the features of employability and by what means they relate to skills attainment.

Employability skills are transportable abilities desired by prospective employees that will give them ample opportunities to be employable in the labour market. Along with practical and professional knowledge, employers sketch out various skills that they demand from the employee. With an adequate possession of employable capabilities, personnel are anticipated to effectively perform their duties based on capability. Wickramasinghe and Perera (2010) defined employability skills as different success abilities, understanding and sterling qualities that assist graduates in gaining employment and being effective in their preferred professions. This, in turn, is of immense benefit to the graduates, to the workers, to the general public and to the economy at large. In the same vein, Wise, Henninger \& Kennan (2011) suggest that graduate employability is a custodian of the definite level of skills ${ }^{1}$, attributes and capabilities that allow graduates to seek and apply for jobs and to maintain those jobs once employed.

These skills are judged to be vital and essential in assisting graduates in not only securing employment but also in attaining greater height (or a higher rank) in the workplace in contemporary society. For the purpose of this study, the focus will be on self-development skills, job interview skills, and job searching skills. Self-development skills are personal or individual skills possessed by the individual to secure, sustain and maintain job opportunities. Examples of these skills include social skills, self-confidence communication, honesty, self-directed writing, listening, and

\footnotetext{
${ }^{1}$ Skills include self-development skills, job searching skills, job interview skills, communication skills, problem-solving skills and analytical skills.
} 
mathematics (which is sometimes referred to as basic academic skills). Job interview skills are skills possessed by the graduates or job seekers in order to succeed in official face-to-face interactions with interviewers. To be successful during the interview session the interviewee should be knowledgeable about the company and its operations. They should also be aware of questioning techniques and have an organized curriculum vitae. Furthermore, job seekers should possess the techniques associated with job search intensity and job search efficacy skills in order to secure available job opportunities (Chavan \& Carter, 2018).

Employability depends on graduate knowledge, skills and attitudes, how they use those assets, and present them to employers. Among the skills demanded of a graduate in any working environment are: critical thinking skills, an ability to learn and adapt in a working environment, communication skills, using initiative and being self-motivated, working under pressure and to deadlines, organizational skills, team working skills, negotiation skills, numeracy, and valuing diversity and difference (El Mansour \& Dean, 2016).

Unemployment has been on the front burner of discourse in Nigeria at the present time. Every year, tertiary institutions which are comprised of Universities, Polytechnics, Monotechnics and Colleges of Education (Harry, Chinyamurindi \& Mjoli, 2018) have been turning out graduates that have persistently congested the labour-market along with the unemployed youths in the nation. The Nigerian economy has been hit with unemployment and has become a legitimate concern of various stakeholders because of its attendant social and economic problems. Unemployment is defined as a situation where people who are qualified and willing to work cannot find a position. It is also defined as an economic condition in which individuals seeking jobs remain unemployed (Wickramasinghe \& Perera, 2010). It can also be seen as the share of the labour force that is without work but available for seeking employment. The National Bureau of Statistics (2019) defined unemployment as persons between the ages of 15-64, who during the referred period were ready for work and painstakingly searching for work, but remained unemployed. A continuous increase in the scourge of unemployment year in and year out corresponds with an increase in the social vices of a society such as kidnapping, money rituals, insurgency, yahoo plus, drug abuse, and armed robbery.

The degree of unemployment has been judged to be a useful tool for the well-being of a particular country over time as it has both social and economic implications. It has been noted that the number of youths graduated from tertiary institutions has been heightened without a monumental increase in job opportunities. This is evident in the information revealed by former Finance Minister Okonjo-Iweala in 2014 that Nigerian tertiary institutions are turning out 1.8 million graduates every year who are willing and ready to take on job in the labour market. The growing nature of graduate youths' unemployment in Nigeria has engendered impedance in the economic growth and development in the country. The following table shows the percentage of youths' unemployment in Nigeria from 2009-2019. 
Table One:

Youth Unemployment from 2009-2019

$\underline{\text { Year }}$

2019

2018

2017

2016

2015

2014

2013

2012

2011

2010

2009
Percentage

6.11

6.03

6.01

6.24

5.31

4.44

3.70

3.69

3.70

3.77

3.76

Source: National Bureau of Statistics (2019)

Available data shows that youth unemployment continuously increased in Nigeria from 2009 to 2019. The increase in the scourge may be associated with several reasons such as job losses, and lack of employability skills needed by the employers. Similarly, the Minister of Labour and Productivity, Chris Ngige on April 13, 2020 lamented that unemployment in Nigeria will hit $33.5 \%$ by 2020 if appropriate measures were not taken. The rising occurrence of unemployment leads to the loss of revenue for individuals, decreases returns for governments, hampers economic growth and jack-ups government spending on social benefits in advanced countries. The business owners all over the country are repeatedly grumbling that some of these graduates, even though they are professionally or technically qualified, are unemployable, in that they are deficient in functional, indispensable abilities or proficiency required of them for employment sustainability (Nwosu \& Chukwudi, 2015).

Among the factors escalating the rate of unemployment in Nigeria is employability which has been the center of this study. Due to this problem, federal, state and local governments have made frantic efforts to contain the menace of unemployment by instructing the tertiary institutions to step up with strategies to produce graduates who will compete favourably in the labour market and be equipped with requisites skills needed to make them employable and to stand independently without necessarily depending on the government for job opportunities. The rate at which this has been accomplished is not crystal clear. The increase in the labour force in Nigeria without a corresponding increase in possession of employability skills have added to the scourge of unemployment. As a result of the upsurge in the menace of unemployment, this study assesses the employability skills of undergraduates at the University of Ilorin. 


\section{Statement of the Problem}

The problem of graduates' employability has been lingering on the lips of higher education administrators in different developing countries. These worries have been accorded the utmost priority in the current climate of the wider labour market. Policymakers continue to emphasize the importance of 'employability skills' in order for graduates to be fully equipped in meeting the challenges of an increasingly flexible labour market as these skills are rarely taught in school. This has been the scourge that inhibits graduates in securing desired jobs. Owolabi, Jumoke \& Oluwatosin (2013) opined that the Nigerian educational system only equips students with knowledge-based learning with the absence of an intellectual ability to appropriately apply knowledge in the working environment.

In spite of extensive ideas in employability skills being manufactured in tertiary institutions, the performance of graduates in the working environment are not in line with employer's expectations (Chavan \& Carter, 2018). This is evident in Nigeria as expectations from graduates are not being fully met by the employers, most especially in the areas of self-development skills, job searching skills, leadership skills, conflict resolution, job interview skills, meta-cognitive skills, critical thinking skills and decision making. Although, reality shows that graduates are performing in areas of social responsibility (i.e., their ability to show self-confidence in the working place). Insufficient performance of graduates in the workroom is, therefore, connected with and ascribed to meagre skill development in the tertiary institutions. There is, however, the need to assess the employability skills of undergraduates in Kwara State, Nigeria. This has been the focus of this research.

Various researchers have tried to identify various factors that determines the high rate of unemployment skills of Nigerian undergraduates. Omoniwa and Adedapo (2017) averse that the current education system does not appear to be producing graduates with generic and essential skills, hence, this leads to a continuous increase in the rate of youth unemployment. Also, Sodipo (2014) conducted research on employability skill development in work integrated learning environments with an emphasis on the best practices in the classroom and placement activities which develop employability skills. The outcome of the study revealed that work integrated learning was considered instrumental in equipping new graduates with the requisite skills to maintain and sustain job opportunities. Aja-Okorie and Adali (2013) and Raji and Gafar's (2018) studies were able to point out that a lack of various skill acquisition programmes in Nigerian universities constitutes poor employability skills on the part of Nigerian undergraduates. Although, various researchers have carried out studies aimed at examining the causes of poor employability skills of Nigerian undergraduates, only a very few researchers have carried out studies that are aimed at investigating the will of undergraduates in acquiring various technical skills while being undergraduates. Many undergraduates do not involve themselves in technical skill acquisition, rather a lot of undergraduates focus on the theoretical part of academics thereby neglecting skill acquisition. This is problematic when applying for jobs that are specifically skilled oriented.

It is against this background that this study assessed the employability skills possessed by undergraduates at the University of Ilorin, Nigeria. 


\section{Purpose of the Study}

The study purpose was to assess employability skills possessed by undergraduates in Kwara State, Nigeria. Precisely, the followings were examined:

1. the level of employability skills possessed by undergraduates at the University of Ilorin.

2. the perceived factors influencing employability of undergraduates at the University of Ilorin

3. the extent to which undergraduates at the University of Ilorin possessed self-development skills

4. the level of ability of undergraduates at the University of Ilorin towards job searching techniques

5. the extent to which undergraduates at the University of Ilorin possessed interview skills

\section{Research Questions}

The following research questions were stated for this work:

1. What is the level of employability skills possessed by undergraduates at the University of Ilorin?

2. What are the perceived factors influencing employability of undergraduates at the University of Ilorin?

3. To what extent do undergraduates at the University of Ilorin possess self-development skills?

4. What is the level of ability of undergraduates at the University of Ilorin towards job searching techniques?

5. To what extent do undergraduates at the University of Ilorin possess interview skills?

\section{Methods}

Descriptive research of the survey design was employed for this study. The design was greatly concerned with the given detailed description of an event as it appeared, with the absence of manipulation of what brought about the event, or what is being observed. This design was chosen because it enables the researcher to make generalizations from the sample respondents on the whole population. The population of this study comprised undergraduates in Kwara state while the target population were undergraduates in the Faculty of Education at the University of Ilorin. A purposive sampling technique was used to choose final year (400 level) undergraduates in the 2018/2019 academic session with an estimated population of 1,033 students. The final year undergraduates were chosen because they were at the verge of graduating and preparing for the labour market. A sample of 353 undergraduates participated in the 
study as recommended by the research advisor in 2006 (with a 95\% confidence level and a 0.05 margin of error). A multi-stage sampling technique was used at the first stage. A simple random sampling technique of a ballot type was used to select four departments out of nine in the Faculty of Education. This was done by using numbers to represent names of each faculty being placed into a spinner. The number that came up was picked, one after the other, without replacement. Secondly, a simple random sampling technique was used to select undergraduates from Faculty of Education. In the third stage, a proportionate sampling technique was used to select 353 respondents from each faculty based on the population of each department as follows:

Table Two:

Selection of Sample Size

\begin{tabular}{rlll}
\hline SN & Department & Population & Sample size \\
\hline 1. & Educational Technology & 1600 & 129 \\
2. & Adult and Primary Education & 1100 & 89 \\
3. & Educational Management & 950 & 77 \\
4. & Social Sciences Education & 712 & 58 \\
& & & \\
& Total & $\mathbf{4 3 6 2}$ & $\mathbf{3 5 3}$ \\
\hline
\end{tabular}

Source: Field Survey, 2019

Lastly, an accidental sampling technique was used to select those undergraduates available at the time of questionnaire distribution.

A self-structured questionnaire designed by the researcher was used to collect data in this study and the instrument was titled "Assessment of Employability Skills of Undergraduates Questionnaire (AESUQ)". The instrument was structured under six sections as follows: Section A: Personal information of the respondents; Section B: Level of employability skills; Section C: Factors that determine employability skills; Section D: Extent of undergraduates self-development skills; Section E: Undergraduates possession of job searching skills; and Section F: Undergraduates possession of Interview Skills. The questionnaire was constructed with closed responses on a Likert typed scale as thus: Above Average $=3$, Average $=2$ and Below Average $=1$ for section B and E; Strongly Agree $(S A=4)$, Agree $(A=3)$, Disagree $(D=2)$ and Strongly Disagree $(\mathrm{SD}=1)$ for section $\mathrm{C}$; To small extent=1, To a moderate extent $=2$, To great extent $=3$ and To a very great extent $=4$ for sections $\mathrm{D}$ and $\mathrm{F}$.

The draft copy of the questionnaire was presented to the experts in Sociology of Education and Educational Research Measurement and Evaluation for face and content validations. The final copy of the questionnaire was produced to incorporate all amendments.

The instrument was also subjected to a reliability test using Cranach's alpha method to determine its internal consistency. Cronbach alpha was adopted because the items involved were in sub-scales and were not dichotomous. This was done by 
administering questionnaires on a sample of 20 students of Kwara State University Malete. The reliability analysis were carried out on each instrument sub-scale and the reliability indexes were reported as follow: for sub-scale B (level of employability skills) which comprises of ten (10) items, the reliability index obtained was $\alpha=0.82$; also, for sub-scale $\mathrm{C}$ (factors determine employability with ten items) had reliability index of $\alpha=0.84$; sub-scale $D$ (extent of self-development skills with ten items) had index of $\alpha=0.86$; sub-scale $E$ (job searching possession skills with ten items) obtained reliability index of $\alpha=0.78$ and sub-scale $F$ (extent of possession of interview skills with ten items) got reliability index of $\alpha=0.81$. This signifies that the items involved in each instrument sub-scale were worthy of retention which indicate that the items had high degree of internal consistency.

Data collected from this study were analysed with both descriptive and inferential statistics. Percentage and frequency counts were used to describe biographical information of sampled respondents while the Mean and Standard Deviation were used to answer research questions 1, 2 and 3.

\section{Ethical Consideration}

Permission was sought from appropriate quarters to administer the instrument. The contents of the questionnaire were clearly explained to the respondents before the administration of the instrument and they were told that they could withdraw their consent at any time. Also, the researcher explained to them that their information will not be disclosed to anybody and it will not be used for anything other than research purposes. The completed questionnaire was received from the respondents when they were done. The administration was carried out by two research assistants to ease the administration of the instrument. The respondents were not motivated in any way to supply needed data.

\section{Results}

\section{Answering the Research Questions}

Research Question One: What is the level of employability skills possessed by undergraduates at the University of Ilorin?

In answering the research question, the collated scores were analyzed using the Mean and Standard Deviation. The benchmark of 2.50 was set for the interpretation of employability level (Above Average, Average and Below Average). Therefore, items found with a mean score above the benchmark of 2.50 would be considered above average, also, the item with its mean score that equals the 2.50 benchmark would be classified as average and the ones where the mean score falls below 2.50 would be judged as below average. The statistics summary is presented in Table 3. 
Table Three:

Level of employability skills possessed by undergraduates at the University of Ilorin

\begin{tabular}{|c|c|c|c|c|c|}
\hline $\mathbf{S} / \mathbf{N}$ & Items & $\mathbf{N}$ & $\begin{array}{l}\text { Standard } \\
\text { Deviation }\end{array}$ & Mean & Remark \\
\hline 1 & I possessed ICT skills. & 353 & .52 & 3.60 & $\begin{array}{l}\text { Above } \\
\text { average }\end{array}$ \\
\hline 2 & $\begin{array}{l}\text { I possessed skills needed for job } \\
\text { interview modes. }\end{array}$ & 353 & .52 & 1.77 & $\begin{array}{l}\text { Below } \\
\text { average }\end{array}$ \\
\hline 3 & I possess integrity skills. & 353 & .61 & 3.66 & $\begin{array}{l}\text { Above } \\
\text { average }\end{array}$ \\
\hline 4 & $\begin{array}{l}\text { I possessed good decision-making } \\
\text { skills. }\end{array}$ & 353 & 80 & 1.42 & $\begin{array}{l}\text { Below } \\
\text { average }\end{array}$ \\
\hline 5 & $\begin{array}{l}\text { I can manage complexity of human } \\
\text { being in workplace. }\end{array}$ & 353 & .01 & 1.64 & $\begin{array}{l}\text { Below } \\
\text { average }\end{array}$ \\
\hline 6 & I have goal oriented abilities. & 353 & .88 & 2.59 & Average \\
\hline 7 & $\begin{array}{l}\text { I can think critically towards } \\
\text { situations. }\end{array}$ & 353 & .66 & 2.54 & Average \\
\hline 8 & $\begin{array}{l}\text { I have multilayered communication } \\
\text { skills. }\end{array}$ & 353 & .28 & 2.95 & Average \\
\hline 9 & I possess good team work spirit. & 353 & .73 & 2.56 & Average \\
\hline 10 & $\begin{array}{l}\text { I can use computer Microsoft word } \\
\text { application. }\end{array}$ & 353 & .68 & 2.12 & $\begin{array}{l}\text { Below } \\
\text { Average }\end{array}$ \\
\hline & Average Mean & 353 & 0.72 & 2.57 & Average \\
\hline
\end{tabular}

Table 3 shows the level of employability skills possessed by undergraduates at the University of Ilorin. The results show that the level of employability skills possessed by undergraduates at the University of Ilorin is at an average level which means they are moderately in possession of the employability skills that are required.

Research Question Two: What are the factors determining the employability of undergraduates at the University of Ilorin?

A cut-off score of 2.50 was used as the baseline for determining participants' responses since the questionnaire items were structured in a four-response-type. Therefore, items found with mean scores equal or above 2.50 were 'considered the factor determining employability of undergraduates while items with mean scores below 2.50 were judged otherwise. 
Table Four:

Perceived factors influencing employability of undergraduates at the University of Ilorin

\begin{tabular}{llcccc}
\hline S/N & \multicolumn{1}{c}{ Items } & N & $\begin{array}{c}\text { Standard } \\
\text { Deviation }\end{array}$ & Mean & Remark \\
\hline 1 & Academic skills & 353 & .53 & 3.44 & Agreed \\
2 & Skills acquisition program & 353 & .53 & 3.61 & Agreed \\
3 & Work culture & 353 & .52 & 3.30 & Agreed \\
4 & Emotional intelligence & 353 & .74 & 3.64 & Agreed \\
$\mathbf{5}$ & Parental entrepreneurial experience & 353 & .75 & 3.45 & Agreed \\
$\mathbf{6}$ & Working experience & 353 & .61 & 3.38 & Agreed \\
$\mathbf{7}$ & Participation in extracurricular activities 353 & .66 & 3.19 & Agreed \\
$\mathbf{8}$ & Self-development skills & 353 & .92 & 3.47 & Agreed \\
$\mathbf{9}$ & Good communication skill & 353 & .86 & 3.23 & Agreed \\
$\mathbf{1 0}$ & Human resources management skill & 353 & .54 & 3.29 & Agreed \\
& & & & &
\end{tabular}

$*$ Mean $\geq 2.50=$ Agreed

Table 4 shows the factors that determine the employability of undergraduates at the University of Ilorin. The results show that all of the factors listed in this study were perceived to a great extent to be influencing the employability skills of undergraduates in Nigerian Universities.

Research Question Three: To what extent do undergraduates at the University of Ilorin possessed self-development skills?

Table Five:

Extent of undergraduates' possession of self-development skills

\begin{tabular}{rlcccl}
\hline S/N & \multicolumn{1}{c}{ Items } & N & $\begin{array}{c}\text { Standard } \\
\text { Deviation }\end{array}$ & Mean & Remark \\
\hline 1 & $\begin{array}{l}\text { I can improve my self-awareness } \\
\text { skill }\end{array}$ & 353 & .52 & 1.35 & To a small extent \\
2 & I can learn on my own & 353 & .67 & 2.38 & $\begin{array}{l}\text { To a moderate } \\
\text { extent }\end{array}$ \\
3 & $\begin{array}{l}\text { I can personally improve my } \\
\text { potentials through practice }\end{array}$ & 353 & .63 & 1.62 & To a small extent \\
4 & $\begin{array}{l}\text { I engage in career training } \\
\text { I study interview past questions }\end{array}$ & 353 & .59 & 1.41 & $\begin{array}{l}\text { To a small extent } \\
\text { To a moderate } \\
\text { extent }\end{array}$ \\
\hline
\end{tabular}




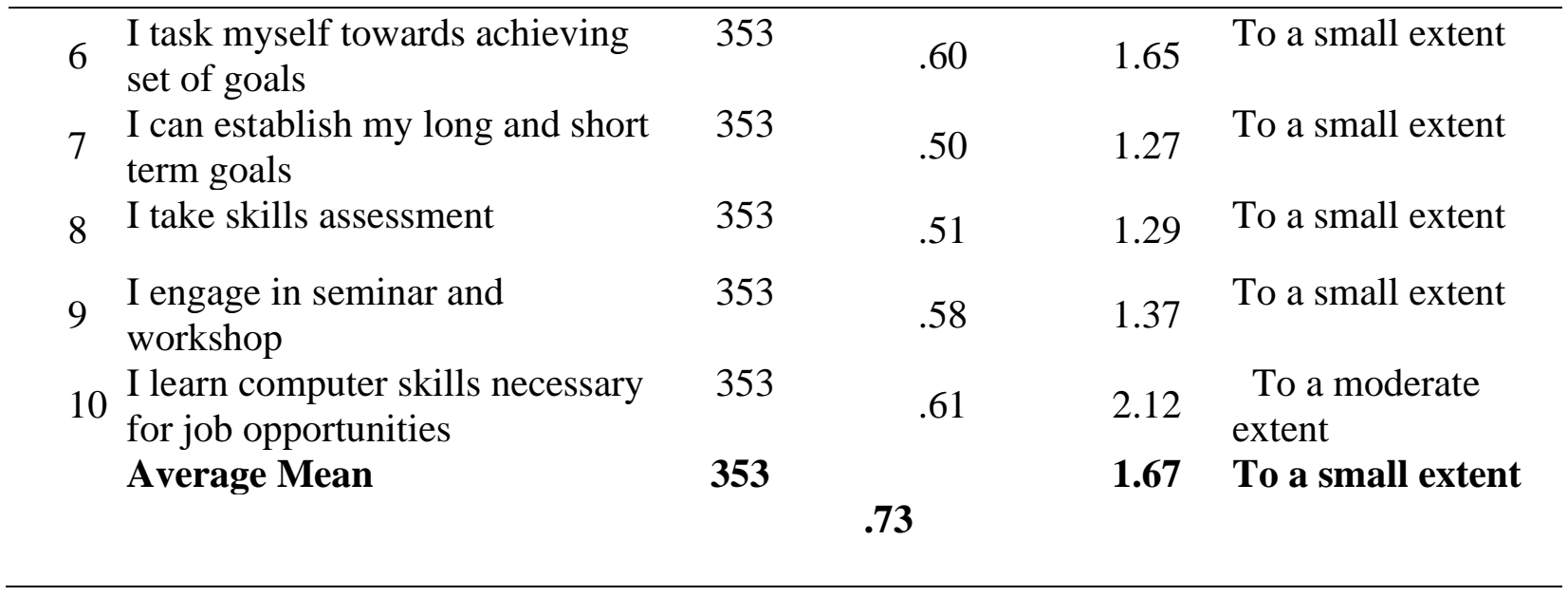

Mean Score: To a small Extent $=1-1.75$; To a Moderate Extent $=1.76-2.41$; To a Great Extent=2.52-3.27, To a Very Great Extent =3.28-4.00.

Data in Table 5 shows the extent to which undergraduates at the University of Ilorin possessed self-development skills. Available data revealed that the Average Mean score of the items was 1.67 with a Standard Deviation of 0.75 which is below the benchmark Mean score of 2.50. This indicates that undergraduates at the University of Ilorin possessed a small extent of self-development skills.

Research Question Four: What do undergraduates at the University of Ilorin possess in terms of job searching techniques?

Table 6:

The level of Undergraduates' Possession of Job Searching Techniques

\begin{tabular}{|c|c|c|c|c|c|}
\hline $\mathbf{S} / \mathbf{N}$ & Items & $\mathbf{N}$ & $\begin{array}{l}\text { Standard } \\
\text { Deviation }\end{array}$ & Mean & Remark \\
\hline 1 & $\begin{array}{l}\text { I read newspaper pages on job } \\
\text { vacancies }\end{array}$ & 353 & .68 & 1.11 & $\begin{array}{c}\text { Below } \\
\text { average }\end{array}$ \\
\hline 2 & $\begin{array}{l}\text { I am on LinkedIn to enhance job } \\
\text { opportunity }\end{array}$ & 353 & .74 & 3.45 & $\begin{array}{c}\text { Above } \\
\text { average }\end{array}$ \\
\hline 3 & $\begin{array}{l}\text { I am on the lookout for any job } \\
\text { application online }\end{array}$ & 353 & .73 & 2.32 & Average \\
\hline 4 & $\begin{array}{l}\text { I registered on companies' graduate } \\
\text { trainees platform }\end{array}$ & 353 & .74 & 1.32 & $\begin{array}{c}\text { Below } \\
\text { average }\end{array}$ \\
\hline 5 & $\begin{array}{l}\text { I make contact and follow-up on job } \\
\text { portals }\end{array}$ & 353 & .85 & 2.22 & Average \\
\hline 6 & $\begin{array}{l}\text { I update elevator speech for various } \\
\text { businesses }\end{array}$ & 353 & .87 & 2.30 & Average \\
\hline 7 & $\begin{array}{l}\text { I belong to social media groups for job } \\
\text { search and scholarships }\end{array}$ & 353 & 1.05 & 2.12 & Average \\
\hline
\end{tabular}




\begin{tabular}{|c|c|c|c|c|c|}
\hline 8 & I am on twitter for job search & 353 & 1.10 & 3.10 & $\begin{array}{c}\text { Above } \\
\text { Average }\end{array}$ \\
\hline 9 & \multirow{3}{*}{$\begin{array}{l}\text { I make a career plan } \\
\text { I update my curriculum vitae as the } \\
\text { need arises } \\
\text { Average Mean }\end{array}$} & 353 & 1.13 & 3.26 & Average \\
\hline 0 & & 353 & .77 & 2.33 & $\begin{array}{c}\text { Above } \\
\text { Average }\end{array}$ \\
\hline & & 353 & 0.87 & 2.56 & Average \\
\hline
\end{tabular}

Below average $=1-1.67$; Average $=1.68-2.34 ;$ Above Average 2.35-3.0

Data in Table 6 signifies the level at which undergraduates at the University of Ilorin possessed job searching skills. Obtainable data shows that the Average Mean score of the items was 2.56 with a Standard Deviation of 0.78 which is the same with the benchmark mean score of 2.50. This indicates that undergraduates at the University of Ilorin averagely possessed job searching skills.

Research Questions Five: To what extent do undergraduates at the University of Ilorin possess interview skills?

Table 7:

The Extent to which Undergraduates of University of Ilorin Possessed Interview Skills

\begin{tabular}{llccc}
\hline S/N & \multicolumn{1}{c}{ Items } & $\begin{array}{c}\text { Standard } \\
\text { Deviation }\end{array}$ & Mean & Remark \\
\hline $1 \quad \begin{array}{l}\text { It is necessary to practice basic interview } \\
\text { questions }\end{array}$ & .81 & 3.42 & To a moderate extent \\
$2 \quad \begin{array}{l}\text { There is need for undersign illegal questions } \\
\text { during interview }\end{array}$ & .76 & 2.45 & To a small extent \\
$3 \quad \begin{array}{l}\text { I understand dress code for interviews. } \\
\text { One has to know the company product and }\end{array}$ & .70 & 2.17 & To a small extent \\
4 & .70 & 2.37 & To a small extent \\
$5 \quad \begin{array}{l}\text { One needs to study interview questions } \\
\text { modes and ethics for better understanding }\end{array}$ & .55 & 2.40 & To a small extent \\
$6 \quad \begin{array}{l}\text { It is better to arrive at interview venue ahead } \\
\text { of scheduled time }\end{array}$ & .48 & 2.76 & To a moderate extent \\
$7 \quad \begin{array}{l}\text { Exhibition of good body gesture during } \\
\text { interview is necessary }\end{array}$ & .55 & 1.72 & To a small extent \\
$8 \quad \begin{array}{l}\text { In attending an interview, one must be } \\
\text { conversant with the company's profile } \\
\text { The head is important to be kept up during } \\
\text { interview }\end{array}$ & .47 & 2.12 & To a small extent \\
$10 \quad \begin{array}{l}\text { One must have copies of resume and CV } \\
\text { ready before going for an interview } \\
\text { Average Mean }\end{array}$ & .52 & 1.68 & To a small extent \\
\hline
\end{tabular}

$*$ Mean $\geq 2.50=$ Agreed 
Table 7 shows the extent to which undergraduates at the University of Ilorin possessed interview skills. Evidence from the table suggests that the Average Mean score of the items was 2.39 with a Standard Deviation of 0.64 which is below the benchmark mean score of 2.50. This indicates that undergraduates at the University of Ilorin to small extent possessed interview skills needed for face interviews.

\section{Discussion}

This study investigated the employability skills of undergraduates at the University of Ilorin, Kwara State, Nigeria. The findings of the study revealed that the level of employability skills possessed by undergraduates at the University of Ilorin were at an average level which means they are not in high possession of employability skills. A sensible description for these outcomes is that students of university were taught the courses that are most often mentally focused on and subject knowledge based instead of being work related activities. The result of the findings are related to the outcomes of the findings which were stated by Dania, Bakar \& Mohamed (2014) on factors influencing the acquisition of employability skills by students of selected technical secondary school in Malaysia. The study involved 521 form five final year Malaysian technical secondary school students in the state of Sabah. Their finding shows that employability skills of vocational secondary school students are moderately high $(\mathrm{M}=3.81, \mathrm{SD}=0.34)$. It is appropriate among tertiary education students to, as a matter of fact, develop more employability skills in order to meet up with the dynamic nature of society. If skills were well developed, it would assist them in securing and maintaining any available opportunities.

The study further revealed that some selected employability skills such as emotional intelligence, good communication skills, skills acquisition programs, human resources management skills, self-developments skills, academic skills, parental entrepreneurial experience and participation in extracurricular activities constitute the factors influencing the employability of undergraduates at the University of Ilorin. The result is contrary to the findings of Chillas, Marks \& Galloway (2015) who found that extra curriculum activity in school does not automatically assist students in obtaining soft skills ability, nevertheless, it indeed boosts students' work experience. On the other hand, Jackson (2014) and Newton (2015) reiterated that work experience helps employees to have a better understanding of the roles and expectations of their occupation. Engaging with professional practitioners enhances their confidence which is sought after by organizations as a determinant for employment (Marks \& Scholarios, 2008). Knowledge added via parents entrepreneurial experience and in the working environment go a long way in assisting graduates to acquire movable individual skills. The outcome attests to a previous investigation carried out by Tran (2015) who saw that university graduates were not adequately furnished with relevant skills needed for the world of work. This was evident in the disconnection between the education and training supplied by the universities and the chances accessible in the labour market.

Furthermore, the study also established that undergraduates at the University of Ilorin, to a small extent, possessed self-development skills. The result corroborates 
with the findings of Sodipo (2014) who discovered that the vast majority of students do not, to a great extent, possess good communication skills, commercial awareness skills and negotiation and persuasion skills. These skills, if adequately possessed, will enable students to realize their potential and become self-reliant (one of the major goals of tertiary education). Also, self-development skills are goals yet to be achieved and is confirmed by Cranmer (2006) that about 4.5 million youths enter the labour market every year without any hope of getting employment for life sustenance.

The study also revealed that undergraduates at the University of Ilorin possessed average job searching techniques. This could be affirmed by the assertion of Sodipo (2014) who stated that our educational system does not adequately train youths to acquire functional requisite skills such as job search intensity and job self-efficacy and job search motive skills that inspire propensity to look for fresh employment. Similarly, the outcomes of the study is in congruence with the assertion of Wanberg, Kanfer \& Rotundo (1999) which states that the higher levels of employment commitment, financial hardship, job-search self-efficacy, and motivation control skill were associated with higher levels of job-search intensity. That is, the higher the possession of those skills, the higher the tendency to look out for new employment.

Lastly, undergraduates at the University of Ilorin, to a small extent, possessed needed basic interview skills. This means that inadequate possession of interview skills can reduce the chances of securing appointment. On the other hand, having the knowledge of it will compel job seekers to complete several practice interviews before the first real interview as this will help to avoid mistakes and improve the chances of getting hired. Kraimer, Greco, Seibert \& Sargent (2019) stated that the possession of interview skills will assist job seekers to embrace a consultant mentality and obviously connect the capability to resolve the distinctive challenges of the organisation. In supporting this Nagendra, Radha \& Naidu (2013) said that it is necessary to be acquainted with basic interview questions and ethics to enhance the chance of been selected.

\section{Conclusion}

The alarming rate of graduate unemployment is of great concern to stakeholders in Nigerian society. This has added to the contemporary social problems bedeviling the country today. In the labour market, the growing concern of employers is that graduates turning out from institutions of higher learning possess inadequate employability skills. From the findings of this study, it was discovered that the majority of undergraduates sampled had moderate employability skills but not ones required of them in the labour market. Hence, this has been the urgent call for all university management, most especially the University of Ilorin to intensify their efforts by placing more emphasis on the employability of undergraduates while at the same time, improving their life long experiences that will bring about competitive opportunity for job opportunities. 


\section{Recommendations}

The following recommendations were made in this study.

1. University management should, as a matter of urgency, create graduate employability programs by injecting skills such as interview skills, job searching skills, entrepreneurial skills and self-development skill program into the available programs. This will enhance undergraduate employability and give them the opportunity to meet up with the need of employers in the labour market.

2. Students are advised to equip themselves with necessary skills needed to create wealth and job opportunities by attending skills acquisition program, emotional intelligence and participation in extracurricular activities as all this may not be provided within the four walls of the school.

3. Students should get more acquainted with innovative and creative techniques necessary to make them self-reliant and employable.

4. National University Commission with the help of experts should invest more in developing the students' talents that are necessary for them to establish themselves in life.

5. It is also of utmost importance for students to know the necessary means of searching for available job opportunities.

6. The school management should invite experts from organization to enlighten and train students on basic interview questions and code of conduct 


\section{References}

Aja-Okorie, U., \& Adali, O. (2013). Achieving youth empowerment through repositioning entrepreneurial education in Nigerian universities: problems and prospects. European Scientific Journal, 9(28). https://pdfs.semanticscholar.org/8d61/c601c62c1b50178dc7078d04f60b689b4 $\underline{6 \mathrm{c} 3 . p \mathrm{pdf}}$

Akhuemonkhan, I. A., Raimi, L., \& Sofoluwe, A. O. (2013). Entrepreneurship education and employment stimulation in Nigeria. Journal of Studies in Social Sciences, 3(1).

Artess, J., Mellors-Bourne, R., \& Hooley, T. (2017). Employability: A review of the literature 2012-2016. https://derby.openrepository.com/handle/10545/621285

Chavan, M., \& Carter, L. (2018). Management students-expectations and perceptions on work readiness. International Journal of Educational Management.

Chillas, S., Marks, A., \& Galloway, L. (2015). Learning to labour: an evaluation of internships and employability in the ICT sector. New Technology, Work and Employment, 30(1), 1-15. https://doi.org/10.1111/ntwe.12041

Cranmer, S. (2006). Enhancing graduate employability: Best intentions and mixed outcomes. Studies in Higher Education, 31(2), 169-184. https://doi.org/10.1080/03075070600572041

Dania, J., Bakar, A. R., \& Mohamed, S. (2014). Factors Influencing the Acquisition of Employability Skills by Students of Selected Technical Secondary School in Malaysia. International Education Studies, 7(2), 117-124. https://eric.ed.gov/?id=EJ1068945

El Mansour, B., \& Dean, J. C. (2016). Employability skills as perceived by employers and university faculty in the fields of human resource development (HRD) for entry level graduate jobs. Journal of Human Resource and Sustainability Studies, 4(01), 39.

Federal Government of Nigeria. (2009). National policy on education. Lagos: NERDC. http://wje.sciedupress.com

Harry, T., Chinyamurindi, W. T., \& Mjoli, T. (2018). Perceptions of factors that affect employability amongst a sample of final-year students at a rural South African university. SA Journal of Industrial Psychology, 44(1), 1-10. http://dx.doi.org/10.4102/sajip.v44i0.1510

Jackson, D. (2014). Testing a model of undergraduate competence in employability skills and its implications for stakeholders. Journal of education and work, 27(2), 220-242. https://doi.org/10.1080/13639080.2012.718750 
Jeswani, S. (2016). Assessment of employability skills among fresh engineering graduates: A structural equation modeling approach. The IUP Journal of Soft Skills, 10(2), 7-43. Retrieved from http://www.ijmra.us/project\%20doc/2019/IJRSS_FEBRUARY2019/IJMRA-1 $\underline{5115 . p d f}$

Kraimer, M. L., Greco, L., Seibert, S. E., \& Sargent, L. D. (2019). An investigation of academic career success: The new tempo of academic life. Academy of Management Learning \& Education, 18(2), 128-152. https://doi.org/10.5465/amle.2017.0391

Lourens, E. (2016). From graduate to employee: Exploring the journeys of first-time entrants into the labour market. Unpublished doctoral dissertation. Cape Town, South Africa: Stellenbosch University.

Marks, A., \& Scholarios, D. (2008). Choreographing a system: skill and employability in software work. Economic and Industrial Democracy, 29(1), 96-124. https://journals.sagepub.com/doi/abs/10.1177/0143831x07085141

Nagendra, K. M., Radha, S., \& Naidu, C. G. (2013). Enhanced industrial employability through new vocational training framework with attitude-skill-knowledge (Ask) model. IUP Journal of Management Research, 12(3).

National Bureau of Statistics (2019). Annual abstract of statistics. https://nigerianstat.gov.ng/elibrary?queries[search]=unemployment

Newton, J. (2015). Learning and Teaching: enhancing student achievement through employability. Thailand European policy dialogue support facility. From http://knit.or.th/th/sites/default/files/upload/13/4.

Nwosu, J. C., \& Chukwudi, J. H. (2015). Entrepreneurship education and the challenges of graduate employability in Nigeria. International Journal of Innovation, Management and Technology, Vol. 9, No. 5, October 2018 https://www.researchgate.net/profile/John_Chukwudi/publication/328190004 Entrepreneurship_Education_and_the_Challenges_of_Graduate_Employabilit y_in_Nigeria/links/5bbdb064299bf1049b78a47c/Entrepreneurship-Educationand-the-Challenges-of-Graduate-Employability-in-Nigeria.pdf

Omoniwa, O. B., \& Adedapo, A. A. (2017). Assessing Nigerian graduate employability. Global Journal of Business Disciplines, 1(2).

Owolabi, H.O., Jumoke, I.O. \& Oluwatosin, A.O. (2013). Effectiveness of basic education in equipping upper basic school final year students in kwara state with employable skills. A paper presented at $15^{\text {th }}$ Annual National Conference of Nigerian Association of Educational Researchers and Evaluators, Held at University of Ilorin, Ilorin, Nigeria 
Raji, A. U., \& Gafar, M. (2018). An assessment of architecture students'perception on the soft and practical skills integration into the curriculum structure for sustainable development in nigeria. Journal of Technology Management and Business, 5(2).

Scholarios, D., Van der Heijden, B. I., Van der Schoot, E., Bozionelos, N., Epitropaki, O., Jedrzejowicz, P.,\& Van der Heijde, C. M. (2008). Employability and the psychological contract in European ICT sector SMEs. The International Journal of Human Resource Management, 19(6), 1035-1055.

Sodipo, O. O. (2014). Employability of tertiary education graduates in Nigeria: closing the skills-gap. Global Journal of Human Resource Management, 2, (3), 28-36. Retrieved http://www.eajournals.org/wp-content/uploads/Employability-of-Tertiary-Edu cation-Graduates-in-Nigeria.pdf

Tran, T. T. (2015). Is graduate employability the 'whole-of-higher-education-issue'? Journal of Education and Work, 28(3), 1-21. https://doi.org/10.1080/13639080. 2014.900167

Tholen, G. (2015). What can research into graduate employability tell us about agency and structure? British Journal of Sociology of Education, 36(5), 766-784. https:// doi.org/10.1080/01425692.2013.847782

Tymon, A. (2013). The student perspective on employability. Studies in Higher Education, 38(6), 841-856. Retrieved from https://doi.org/10.1080/03075079.2011.604408 on May 12th, 2019.

Wanberg, C. R., Kanfer, R., \& Rotundo, M. (1999). Unemployed individuals: Motives, job-search competencies, and job-search constraints as predictors of job seeking and reemployment. Journal of Applied psychology, 84(6), 897.

Weligamage, S. S. (2009). Graduates ${ }^{\text {ee }}$ Employability Skills: Evidence from Literature Review. Asaihl, May, 115-125. http://www.kln.ac.lk/uokr/ASAIHL/SubThemeA8.pdf

Wickramasinghe, V., \& Perera, L. (2010). Graduates', university lecturers' and employers' perceptions towards employability skills. Education and Training, 52(3), 226-244. https://doi.org/10.1108/00400911011037355

Wise, S., Henninger, M., \& Kennan, M. A. (2011). Changing trends in LIS job advertisements. Australian academic \& research libraries, 42(4), 268-295. https://www.tandfonline.com/doi/abs/10.1080/00048623.2011.10722241 